УДК 004.056.5

\title{
Пархомов В.А.
}

\section{ПРОБЛЕМА ОЦЕНКИ СКРЫТЫХ УГРОЗ ИНФОРМАЦИОННОЙ БЕЗОПАСНОСТИ}

\begin{abstract}
Анотація:
Представлені матеріали статистичних досліджень за реєстращійними даними та даним опитувань проблем обліку, класифікації та аналізу злочинів у сфері комп 'ютерної інформації. Обговорюються проблеми тлумачення поняття “комп'ютерна злочинність”, очінка ї̈ величини та можливих причин ї̈ латентної складової. Вжита спроба оцінки латентної складової комп 'ютерної злочинності на основі загальної теорії систем (модульної теорії соиіуму).
\end{abstract}

\section{Аннотация:}

Представлены материаль статистических исследований по регистрачионным данным и данным опросов проблем учёта, классификаџии и анализа преступлений в сфере компьютерной информации. Обсуждается проблемы толкования понятия «компьютерная преступность», оченок её величины и возможных причин её латентной составляющей. Предпринята попытка оиенки латентной составляющей компьютерной преступности на основе общей теории систем (модульной теории социума).

\section{Abstract:}

The materials of statistical studies on registration data and survey data accounting problems, classification and analysis of crimes in the sphere of computer information are given. The problem of the interpretation of "computer crime", the estimates of its magnitude and possible reasons for its latent component are discussed. An attempt has been made to estimate the latent component of computer crime on the basis of general systems theory (the theory of modular society). 